\title{
Acanthocyte Count
}

National Cancer Institute

\section{Source}

National Cancer Institute. Acanthocyte Count. NCI Thesaurus. Code C74699.

The determination of the number of acanthocytes present in a sample. 